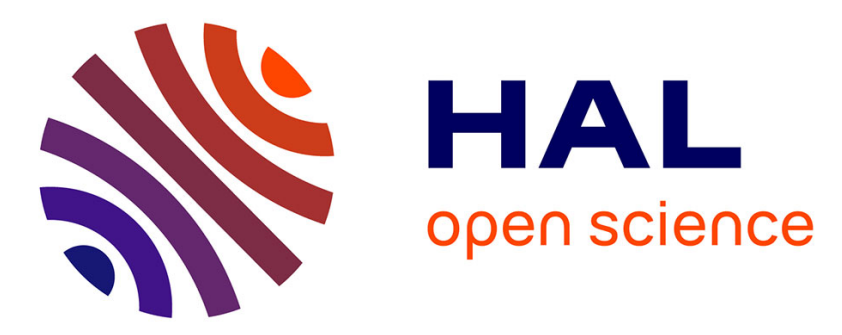

\title{
Boron-doped diamond dual-plate microtrench electrode for generator-collector chloride/chlorine sensing
}

\author{
Andrew James Gross, Frank Marken
}

\section{To cite this version:}

Andrew James Gross, Frank Marken. Boron-doped diamond dual-plate microtrench electrode for generator-collector chloride/chlorine sensing. Electrochemistry Communications, 2014, 46, pp.120123. 10.1016/j.elecom.2014.06.025 . hal-03015168

\section{HAL Id: hal-03015168 \\ https://hal.science/hal-03015168}

Submitted on 19 Nov 2020

HAL is a multi-disciplinary open access archive for the deposit and dissemination of scientific research documents, whether they are published or not. The documents may come from teaching and research institutions in France or abroad, or from public or private research centers.
L'archive ouverte pluridisciplinaire HAL, est destinée au dépôt et à la diffusion de documents scientifiques de niveau recherche, publiés ou non, émanant des établissements d'enseignement et de recherche français ou étrangers, des laboratoires publics ou privés. 
Citation for published version:

Gross, A \& Marken, F 2014, 'Boron-Doped Diamond Dual-Plate Microtrench Electrode for Generator-Collector Chloride/Chlorine Sensing', Electrochemistry Communications, vol. 46.

Publication date:

2014

Document Version

Early version, also known as pre-print

Link to publication

Crown Copyright @ 2014

\section{University of Bath}

\section{Alternative formats \\ If you require this document in an alternative format, please contact: openaccess@bath.ac.uk}

\section{General rights}

Copyright and moral rights for the publications made accessible in the public portal are retained by the authors and/or other copyright owners and it is a condition of accessing publications that users recognise and abide by the legal requirements associated with these rights.

\section{Take down policy}

If you believe that this document breaches copyright please contact us providing details, and we will remove access to the work immediately and investigate your claim. 


\title{
Boron-doped diamond dual-plate microtrench electrode for generator-collector chloride/chlorine sensing
}

\author{
Andrew J. Gross *, Frank Marken \\ Department of Chemistry, University of Bath, Bath, BA2 7AY, UK
}

\section{A R T I C L E I N F O}

\section{Article history:}

Received 29 May 2014

Received in revised form 26 June 2014

Accepted 26 June 2014

Available online 5 July 2014

\section{Keywords:}

Boron-doped diamond electrode

Sensor

Chloride

Hydroxyl

Redox cycling

\begin{abstract}
A B S T R A C T
A novel generator-collector dual-plate boron-doped diamond microtrench sensor is fabricated and its operation demonstrated for chloride/chlorine detection in the harsh anodic potential range. Detection is made sensitive by minimising the inter-electrode gap to $\leq 10 \mu \mathrm{m}$ wide and setting the generator and collector potentials to enable repetitive redox cycling. The concentration and potential-dependant impact on the generator and collector currents are reported and optimised conditions suitable for quantitative determination are demonstrated. The diffusional redox cycling currents for chloride in buffer solution are kinetically controlled and first order over a concentration range of 1 to $140 \mathrm{mM}$.
\end{abstract}

Crown Copyright $@ 2014$ Published by Elsevier B.V. All rights reserved.

\section{Introduction}

Generator-collector dual-plate sensor electrodes have been pioneered by Anderson [1,2] and Reilley [1-3] and treated theoretically, for example, by Peters and Hubbard [4]. The benefit of mass transport enhancement of redox-active species was recognised early on and applied in particular for the study of reaction kinetics [1,2]. More recently in pioneering work by Lemay, Wolfrum and coworkers [5-7], dual-plate sensor systems have been developed down to the nanoscale opening up the possibility of single molecule detection [8].

Recent applications of dual-plate or microtrench electrodes include femtolitre $\mathrm{pH}$ titration [9], ion transport studies [10], $\mathrm{pH}$ modulation [11], and analytical detection of dopamine and ascorbate [12] and cysteine/cysteine [13]. A severely limiting factor of current dualelectrodes is surface corrosion and stability under harsh anodic and cathodic potentials. One possibility to overcome this limitation is to employ $\mathrm{sp}^{3}$-hybridised carbon electrodes such as boron-doped diamond (BDD). BDD has been applied in electroanalysis for many years $[14,15]$ due to benefits in particular at extreme anodic conditions where reactive intermediates may be studied, such as hydroxyl radicals, without significant deterioration of the electrode [16,17]. Macpherson and coworkers very recently reported a method for fabricating BDD co-planar dual-electrodes that offers excellent reproducibility and versatility and a minimum feature size of $50 \mu \mathrm{m}$ [18].

\footnotetext{
* Corresponding author. Tel.: + 44744058597

E-mail address: A.Gross@bath.ac.uk (A.J. Gross).
}

In this work, we describe for the first time a simple and low-cost method for the fabrication of dual-plate or "trench" BDD electrodes with low microscale inter-electrode gap size. Chloride/chlorine detection is demonstrated and the special case of gas evolving electrode processes in microtrench geometries is discussed.

\section{Experimental}

\subsection{Reagents}

Sodium chloride (98\%), potassium chloride ( $\geq 99 \%$ ), mono-sodium phosphate monohydrate (98-102\%), di-sodium hydrogen phosphate heptahydrate (98-102\%), sulphuric acid ( $\geq 95-98 \%)$, hydrogen peroxide (30 wt.\% in water), acetone ( $\geq 99.5 \%$ ) and isopropyl alcohol ( $\geq 99.5 \%$ ) were purchased from Sigma-Aldrich, UK. Hexaammineruthenium (III) chloride $\left(\mathrm{Ru}\left(\mathrm{NH}_{3}\right)_{6} \mathrm{Cl}_{3}, 99 \%\right)$ and SU-8 2002 negative photoresist were purchased from Strem Chemicals and Microchem Corp., respectively. Aqueous solutions were prepared using ultrapure water at $20^{\circ} \mathrm{C}$ (resistivity $\geq 18.2 \mathrm{M} \Omega \mathrm{cm}$ ).

\subsection{Instrumentation}

Electrochemical measurements were performed at $20 \pm 2{ }^{\circ} \mathrm{C}$ using an SP-300 bipotentiostat (Biologic, France). A four-electrode cell was employed with a Pt wire counter electrode, saturated calomel electrode (SCE, Radiometer), and the two working electrodes of the microtrench. A PWM32 spin coater (Headway) was used to spin photoresist. Scanning electron microscopy (SEM) images were obtained with a JSM-6480LV (JEOL, Japan). 


\subsection{Electrode fabrication}

BDD-coated p-doped $\mathrm{Si}$ substrates ( $300 \mathrm{~nm} \mathrm{BDD,} \mathrm{SiO}_{2} / \mathrm{Si}_{3} \mathrm{~N}_{4}$ interlayer, $8000 \mathrm{ppm}$ doping and resistivity $=10 \mathrm{~m} \Omega \mathrm{cm}$ ) were purchased from NeoCoat SA, Switzerland. The $5 \mathrm{~mm} \times 20 \mathrm{~mm}$ substrates were first rinsed successively with ultrapure water, acetone and isopropyl alcohol then dried with a stream of nitrogen. Kapton tape (Farnell, UK) was applied on the top of the substrates at one end to define $\mathrm{a} \approx 5 \mathrm{~mm} \times$ $5 \mathrm{~mm}$ region for electrical contact. The BDD substrates were subsequently spin-coated with a single coat of SU-8-2002 photoresist using a first step at $500 \mathrm{rpm}$ (15 s) and a second step at $3000 \mathrm{rpm}$ (30 s). Next, the Kapton tape was removed and the two substrates were pressed together face-to-face. The substrates were placed on a hot plate pre-heated to $90{ }^{\circ} \mathrm{C}$ for 2 min then heated at $160{ }^{\circ} \mathrm{C}$ for $5 \mathrm{~min}$. After cooling to room temperature, the end of the BDD electrode was sliced-off with a diamond cutter (Isomet 1000, Buehler) and polished using decreasing grits of SiC abrasive paper (Buehler). The SU-8 layer was partially etched out using piranha solution ( $5: 1$ sulphuric acid:hydrogen peroxide) to form the trench (Fig. 1). SEM images in Fig. 1b and c demonstrate the trench width of approximately $9 \pm 1 \mu \mathrm{m}$.

\section{Results and discussion}

3.1. Generator-collector voltammetry at a BDD dual-plate sensor I: aqueous $\mathrm{Ru}\left(\mathrm{NH}_{3}\right)_{6}^{3+/ 2+}$

Initial experiments were performed to characterise the reactivity of the BDD electrode and to calibrate the trench depth. Fig. 1d shows a schematic depiction of the $\mathrm{Ru}\left(\mathrm{NH}_{3}\right)_{6}^{3+/ 2+}$ redox system. Fig. 1e and $\mathrm{f}$ shows voltammograms for the reduction of $1 \mathrm{mM} \mathrm{Ru}\left(\mathrm{NH}_{3}\right)_{6}^{3+}$ at the generator electrode with the collector potential held at $0.35 \mathrm{~V}$ vs. SCE for the back-oxidation (Eq. (1)).

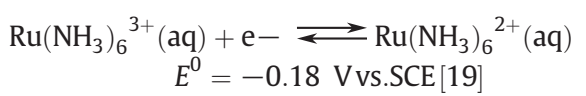

When changing the scan rate, the generator current response is affected but the collector current response remains very stable, free of capacitive current components and sigmoidal in shape (Fig. 1e and f). The collector response is therefore consistent with mass-transport controlled current amplification in the microtrench. Switching the generator and collector electrodes allows the same voltammetric responses to be obtained (Fig. 1f), indicative of a symmetric and well-defined electrode geometry.

The approximate trench depth is obtained by applying the Nernst diffusion layer model [9] and ignoring edge effects (Eq. (2)).

Trench depth $=\frac{I_{\lim } \times \delta}{n F D w c}=7 \pm 2 \mu \mathrm{m}$

In this equation $I_{\text {lim }}$ is the collector limiting current (see Fig. 1e, $i$ ) $=$ $0.33 \mu \mathrm{A}, \delta$ is trench width $=9 \pm 1 \mu \mathrm{m}, n=1$ for $\mathrm{Ru}\left(\mathrm{NH}_{3}\right)_{6}^{3+/ 2+}, F$ is the Faraday constant, $D$ is the diffusion coefficient $=9.1 \times 10^{-10} \mathrm{~m}^{2} \mathrm{~s}^{-1}$ [19], $w$ is the electrode width $=5 \mathrm{~mm}$ and $c$ is $1 \mathrm{~mol} \mathrm{~m}^{-3}$ to give trench depth. The estimated microtrench depth here is $7 \pm 2 \mu \mathrm{m}$, which suggests a rather shallow trench with an aspect ratio of approximately
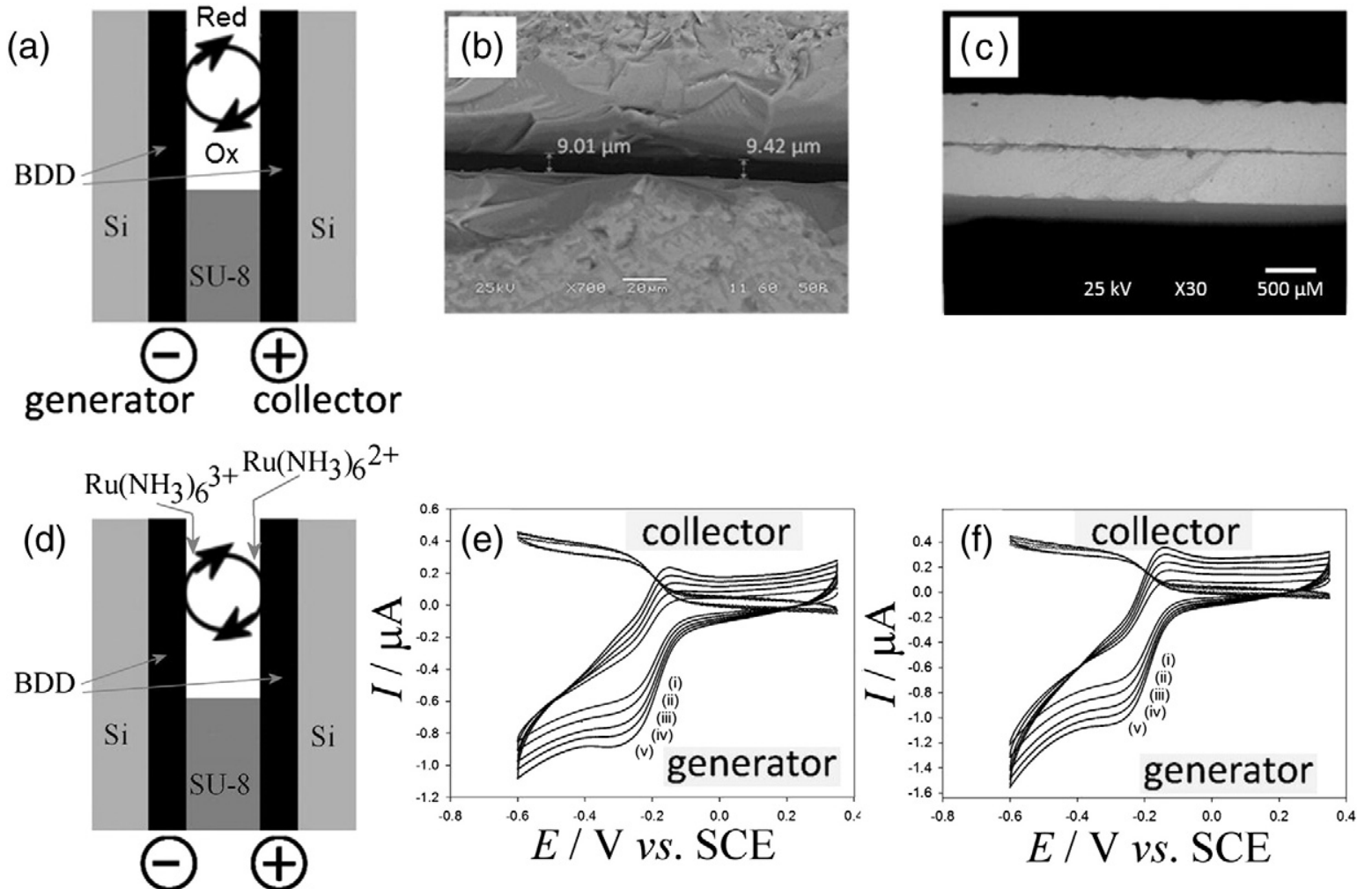

generator collector

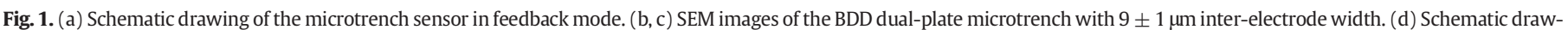

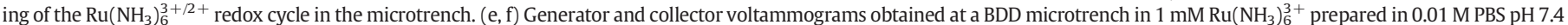

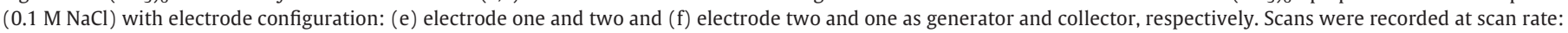
(i) $20 \mathrm{mV} \mathrm{s}^{-1}$, (ii) $40 \mathrm{mV} \mathrm{s}^{-1}$, (iii) $60 \mathrm{mV} \mathrm{s}^{-1}$, (iv) $80 \mathrm{mV} \mathrm{s}^{-1}$ and (v) $100 \mathrm{mV} \mathrm{s}^{-1}$. Collector potential fixed at $0.35 \mathrm{~V}$ vs. SCE. 


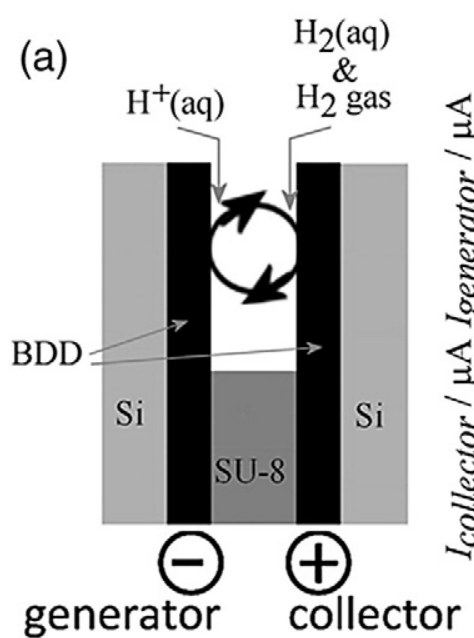

(b)
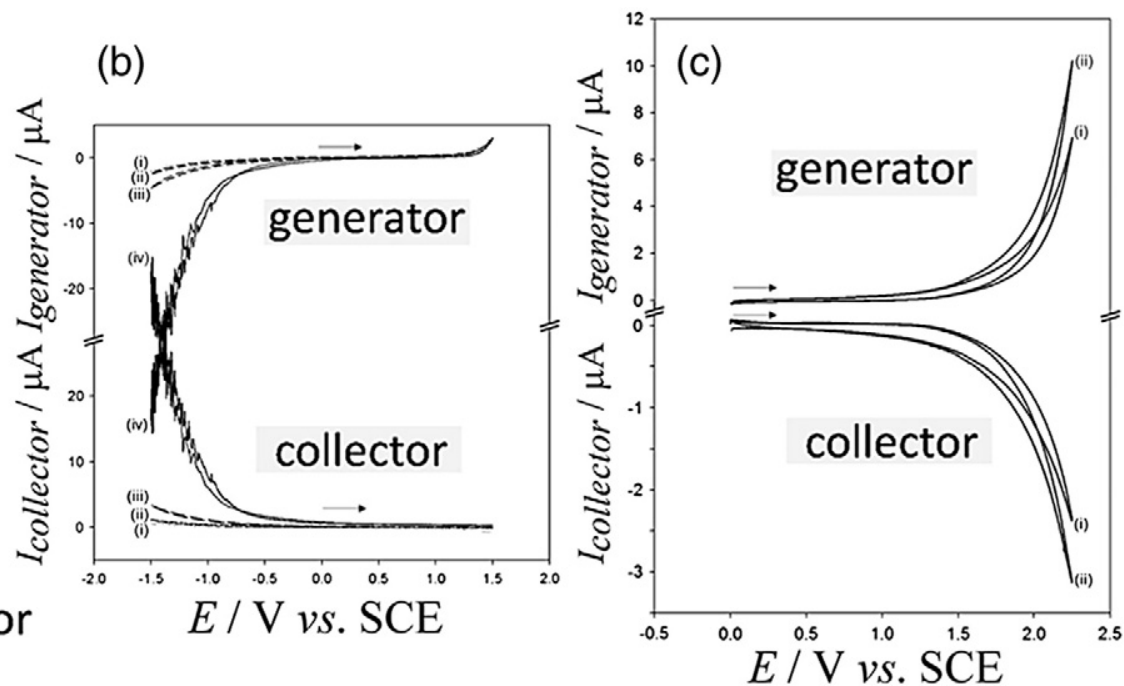

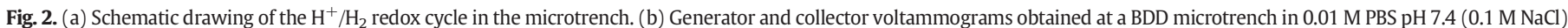

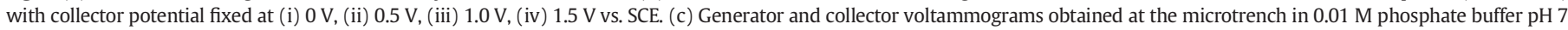
(i) before and (ii) after addition of $5 \mathrm{mM} \mathrm{KCl}$ with the collector potential fixed at $0.0 \mathrm{~V}$ vs. SCE. All scans recorded at $20 \mathrm{mV} \mathrm{s}$.

one. This is consistent with the appearance of peak features in the generator current responses in Fig. 1e and $\mathrm{f}$.

\subsection{Generator-collector voltammetry at a BDD dual-plate sensor II: aqueous phosphate buffer saline (PBS) pH 7.4}

When exploring the potential window for the dual-plate BDD electrode in $0.01 \mathrm{M}$ PBS $\mathrm{pH} 7.4$, both anodic and cathodic processes are observed. Fig. 2b shows significant current signals when the generator potential is scanned into the negative potential region (after first scanning in the positive direction). The generator and collector current responses are symmetric and attributed here to hydrogen evolution (proton reduction) at the generator coupled to hydrogen oxidation at the collector. This process is most pronounced when the collector potential is held at $1.5 \mathrm{~V}$ vs. SCE (Fig. 2b, iv) where a noise component in the current response is consistent with transient gas bubble effects. The solubility of hydrogen gas in aqueous media is low [20] but the formation of bubbles takes time and therefore microtrench measurements are possible substantially beyond the solubility limit [9].

More interesting here is the anodic potential range. In Fig. 2b, the onset of a generator response is observed at $1.5 \mathrm{~V}$ vs. SCE. In Fig. 2c, the potential window is expanded into the positive potential range.
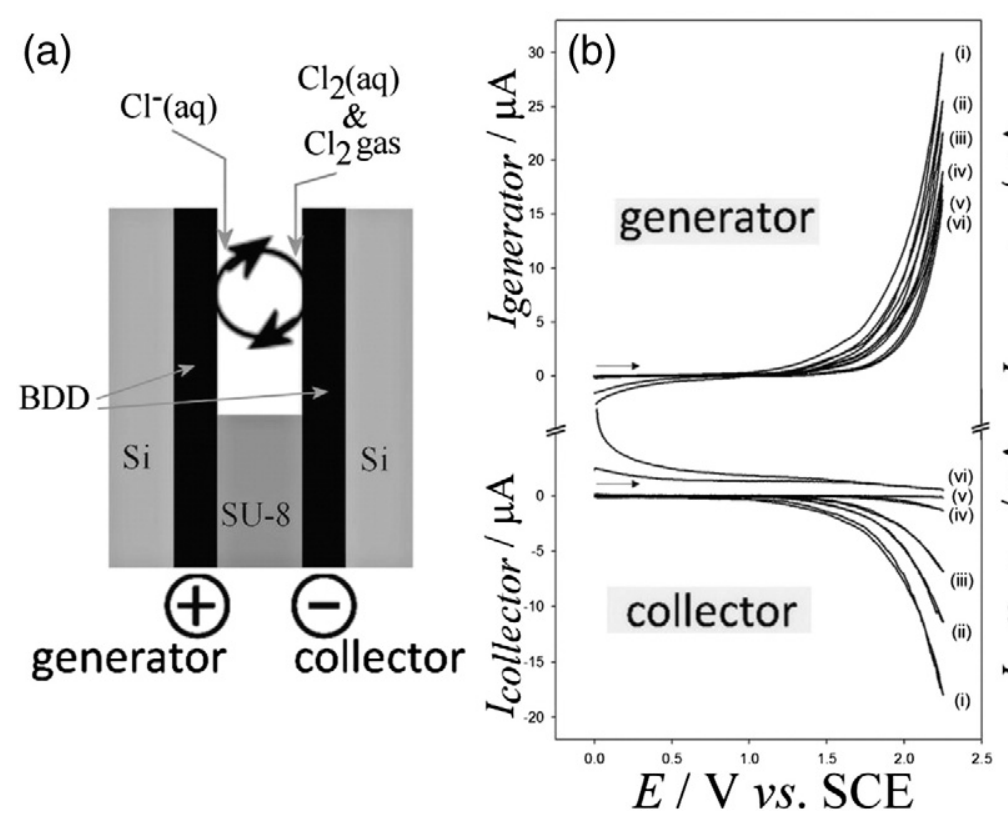

(c)

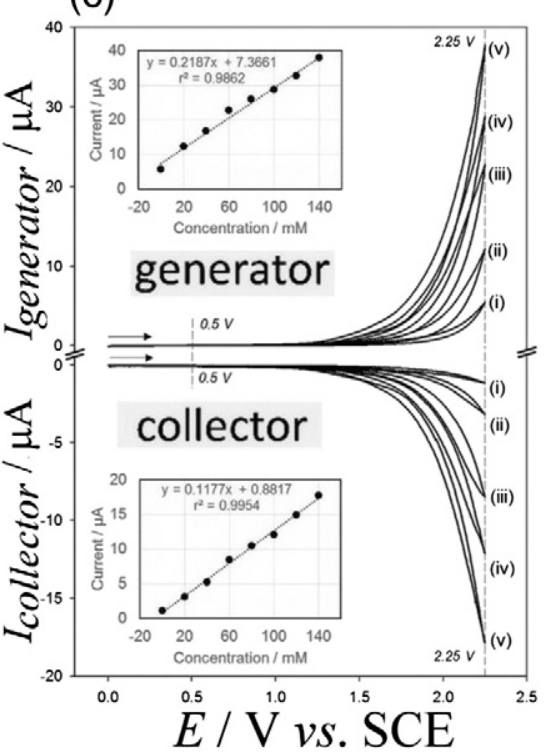

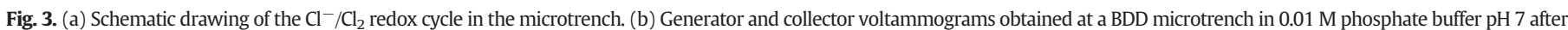

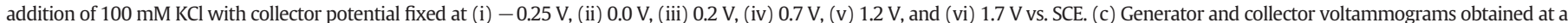

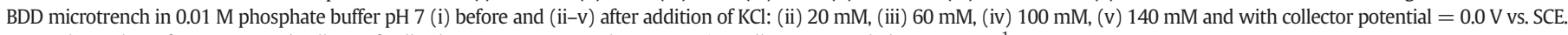
Insets show plots of generator and collector feedback currents versus $\mathrm{KCl}$ concentration. All scans recorded at $10 \mathrm{mV} \mathrm{s}^{-1}$. 
With the collector potential held at $0.0 \mathrm{~V}$ vs. SCE, an increase in currents with chloride addition ( $5 \mathrm{mM} \mathrm{KCl}$ ) is observed. The current increase is tentatively attributed to the chloride/chlorine cycle at BDD (Eq. (3)) [21].

$$
\begin{aligned}
& 2 \mathrm{Cl}^{-}(\mathrm{aq}) \rightleftarrows \mathrm{Cl}_{2}(\mathrm{aq})+2 \mathrm{e}^{-} \\
& E^{0}=1.60 \text { Vvs.SCE }
\end{aligned}
$$

The background current response at the generator and collector electrodes is likely to be associated with the oxidation of water to form oxygen.

\subsection{Generator-collector voltammetry at a BDD dual-plate sensor III: aqueous chloride/chlorine}

When changing the collector potential (see Fig. 3b), the cathodic $\mathrm{Cl}_{2} / \mathrm{Cl}^{-}$current response at the collector is most clearly observed at $0.0 \mathrm{~V}$ vs. SCE, suggesting a back-reaction where chlorine is reduced back to chloride. The ambient solubility of chlorine gas in aqueous media is approximately $22 \mathrm{mM}$ [22] with supersaturation close to the anode likely. Effects from other species such as $\mathrm{Cl}_{3}^{-}$and $\mathrm{ClO}^{-}$are possible, but assumed here to be small. The $9 \mu \mathrm{m}$ inter-electrode gap suggests an average diffusion time for chloride from one electrode to the other of only $\approx 40 \mathrm{~ms}$, based on $\tau=\delta^{2} / D$. With further reduction in the gap size it should be possible to further out run follow-up reactions.

The effect of changing the chloride concentration is shown in Fig. $3 \mathrm{c}$ with both generator and collector electrodes showing similar exponentially increasing current responses with increasing addition of chloride. The plot of the collector current (evaluated as the current at $2.25 \mathrm{~V}$ minus the background current at $0.50 \mathrm{~V}$ vs. SCE) is linear in the range $1 \mathrm{mM}$ to $140 \mathrm{mM}$ chloride with a small intercept due to the underlying oxygen evolution. The current at $2.25 \mathrm{~V}$ vs. SCE is approaching $50 \%$ of the estimated mass transport controlled current (based on Eq. (2) and $D_{\text {chloride }}=2 \times 10^{-9} \mathrm{~m}^{2} \mathrm{~s}^{-1}$ [23]). The kinetically controlled part of the microtrench current can be expressed in first approximation based on $I_{o x}=F A k_{o x}\left[\mathrm{Cl}^{-}\right]$and $I_{\text {red }}=2 F A k_{\text {red }}\left[\mathrm{Cl}_{2}\right]$ with $\left[\mathrm{Cl}_{2}\right] /\left[\mathrm{Cl}^{-}\right]=$ $k_{\text {ox }} / 2 k_{\text {red }}$ and with $c_{0}=\left[\mathrm{Cl}^{-}\right]+2\left[\mathrm{Cl}_{2}\right]$ to give Eq. (4).

$I_{\text {lim, }, \text { inetic }}=F A c_{0} \frac{k_{o x} \times k_{\text {red }}}{k_{o x}+k_{\text {red }}}$

With the collector potential very negative, $k_{\text {red }}$ can be assumed to be very high, which leaves $I_{\text {lim,kinetic }}=F A c_{0} k_{o x}$ and therefore a Tafel-like dependence up to the current densities where mass transport corrections must be applied.

In conclusion, a new BDD dual-plate microtrench electrode system has been developed and its application demonstrated for the analysis of chloride in aqueous buffer solution. The fabrication method is simple yet provides access to robust electrodes with a small microscale inter-electrode gap size of $9 \pm 1 \mu \mathrm{m}$. The generation of relatively high concentrations of chlorine in the microtrench (beyond the solubility limit) is unique and demonstrated here to be of analytical value. A wide range of analytical applications are envisaged using these electrodes, especially in view of the formation of chlorine, or reactive intermediates such as hydroxyl radicals, to capture analytes which are not sufficiently electroactive on their own. The availability of hydroxyl radicals at high potentials opens up new opportunities for the indirect determination of total organic carbon (TOC). In future work smaller inter-electrode gap size and larger aspect ratios should be possible by changing the SU-8 deposition and acid etching protocols, to improve further the analytical performance of these electrodes.

\section{Conflict of interest}

The authors declare that there are no conflicts of interest.

\section{Acknowledgements}

A.J.G. and F.M. gratefully acknowledge the Engineering and Physical Sciences Research Council (EP/I028706/1) for financial support.

\section{References}

[1] L.B. Anderson, C.N. Reilley, J. Electroanal. Chem. 10 (1965) 295

[2] B. McDuffie, L.B. Anderson, C.N. Reilley, Anal. Chem. 38 (1966) 883.

[3] C.N. Reilley, Rev. Pure Appl. Chem. 18 (1968) 137.

[4] A.T. Hubbard, D.G. Peters, CRC Crit. Rev. Anal. Chem. 3 (1973) 201

[5] S.G. Lemay, S. Kang, K. Mathwig, P.S. Singh, Acc. Chem. Res. 46 (2012) 369.

6] L. Rassaei, P.S. Singh, S.G. Lemay, Anal. Chem. 83 (2011) 3974.

[7] M. Huske, R. Stockmann, A. Offenhausser, B. Wolfrum, Nanoscale 6 (2014) 589

[8] P.S. Singh, E. Kätelhön, K. Mathwig, B. Wolfrum, S.G. Lemay, ACS Nano 6 (2012) 9662.

[9] S.E.C. Dale, A. Vuorema, M. Sillanpää, J. Weber, A.J. Wain, E.O. Barnes, R.G. Compton, F. Marken, Electrochim. Acta 125 (2014) 94.

[10] S.E.C. Dale, Y. Chan, P.C. Bulman Page, E.O. Barnes, R.G. Compton, F. Marken, Electrophoresis 34 (2013) 1979

[11] S.E.C. Dale, F. Marken, Faraday Discuss. 164 (2013) 349

[12] M.A. Hasnat, A.J. Gross, S.E.C. Dale, E.O. Barnes, R.G. Compton, F. Marken, Analyst 139 (2014) 569.

[13] J.L. Hammond, A.J. Gross, P. Estrela, J.I. Valcarcel, S.J. Green, C.P. Winlove, P.G. Winyard, N. Benjamin, F. Marken, Anal. Chem. (2014), http://dx.doi.org/10.1021/ ac501321e.

[14] R.G. Compton, J.S. Foord, F. Marken, Electroanalysis 15 (2003) 1349.

[15] J.H.T. Luong, K.B. Male, J.D. Glennon, Analyst 134 (2009) 1965.

[16] S.R. Waldvogel, B. Elsler, Electrochim. Acta 82 (2012) 434

[17] A. Kapałka, G. Fóti, C. Comninellis, Electrochim. Acta 54 (2009) 2018.

[18] M.B. Joseph, E. Bitziou, T.L. Read, L. Meng, N.L. Palmer, T.P. Mollart, M.E. Newton, J.V. Macpherson, Anal. Chem. 86 (2014) 5238.

[19] F. Marken, J.C. Eklund, R.G. Compton, J. Electroanal. Chem. 395 (1995) 335

[20] T. Seo, R. Kurokawa, B. Sato, Med. Gas Res. 2 (2012) 1.

[21] A.J. Bard, R. Parsons, J. Jordan, Standard Potentials in Aqueous Solutions, Marcel Dekker, New York, 1985

[22] Y. Gendel, O. Lahav, Electrochim. Acta 63 (2012) 209.

[23] R. Mills, V.M.M. Lobo, Self-diffusion in Electrolyte Solutions: A Critical Examination of Data Compiled From the Literature, Elsevier, Amsterdam, 1989. 